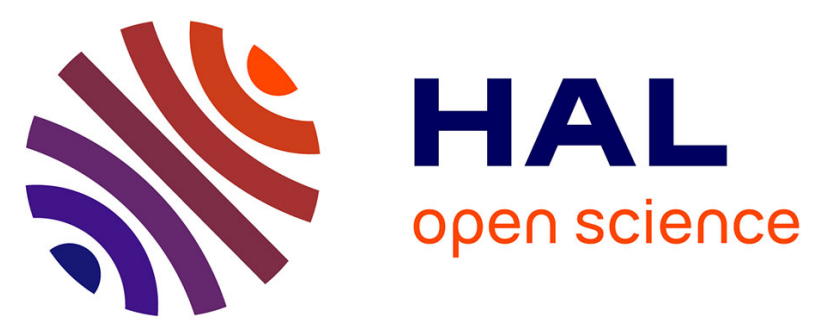

\title{
Barium complexes with crown-ether-functionalised amidinate and iminoanilide ligands for the hydrophosphination of vinylarenes
}

Erwann Le Coz, Hanieh Roueindeji, Thierry Roisnel, Vincent Dorcet, Jean-François Carpentier, Yann Sarazin

\section{To cite this version:}

Erwann Le Coz, Hanieh Roueindeji, Thierry Roisnel, Vincent Dorcet, Jean-François Carpentier, et al.. Barium complexes with crown-ether-functionalised amidinate and iminoanilide ligands for the hydrophosphination of vinylarenes. Dalton Transactions, 2019, 48 (25), pp.9173-9180. 10.1039/c9dt01512d . hal-02150460

HAL Id: hal-02150460

https://hal-univ-rennes1.archives-ouvertes.fr/hal-02150460

Submitted on 8 Jul 2019

HAL is a multi-disciplinary open access archive for the deposit and dissemination of scientific research documents, whether they are published or not. The documents may come from teaching and research institutions in France or abroad, or from public or private research centers.
L'archive ouverte pluridisciplinaire HAL, est destinée au dépôt et à la diffusion de documents scientifiques de niveau recherche, publiés ou non, émanant des établissements d'enseignement et de recherche français ou étrangers, des laboratoires publics ou privés. 


\title{
Barium complexes with crown-ether-functionalised amidinate and iminoanilide ligands for the hydrophosphination of vinylarenes $\uparrow$
}

(a contribution to the special issue of Dalton Transactions dedicated to nitrogen-based ligands)

\author{
Erwann Le Coz, ${ }^{\ddagger}$ Hanieh Roueindeji, ${ }^{\ddagger}$ Thierry Roisnel, Vincent Dorcet, \\ Jean-François Carpentier and Yann Sarazin*
}

Univ Rennes, CNRS, ISCR (Institut des Sciences Chimiques de Rennes) - UMR 6226, F-35000 Rennes, France.

Corresponding author: yann.sarazin@univ-rennes1.fr

$\uparrow$ Electronic supplementary information (ESI) available: full experimental details including NMR spectra and crystallographic data for CCDC 1896037-1896039 and 1897231. 


\begin{abstract}
The detailed multistep syntheses of two nitrogen-based sterically congested iminoanilidine and amidine proligands bearing a tethered 15 -member aza-ether-crown macrocycle, namely $\left\{\mathrm{I}^{\wedge} \mathrm{A}^{\text {crown }}\right\} \mathrm{H}$ and $\left\{A m^{\text {crown }}\right\} \mathrm{H}$, are reported. These proligands react with $\left.\left[\mathrm{Ba}\left\{\mathrm{N}\left(\mathrm{SiMe}_{2} \mathrm{H}\right)_{2}\right\}_{2} \text {. (thf }\right)_{n}\right]$ to generate the heteroleptic barium complexes $\left[\left\{\mathrm{I}^{\wedge} \mathrm{A}^{\text {crown }}\right\} \mathrm{BaN}\left(\mathrm{SiMe}_{2} \mathrm{H}\right)_{2}\right](\mathbf{5})$ and $\left[\left\{\mathrm{Am}^{\text {crown }}\right\} \mathrm{BaN}\left(\mathrm{SiMe}_{2} \mathrm{H}\right)_{2}\right](\mathbf{6})$ in high yields. These complexes exhibit high coordination numbers (resp. eight and seven), and are in addition stabilised by mild $\mathrm{Ba} \cdots \mathrm{H}-\mathrm{Si}$ interactions. Unusually for oxophilic elements such as barium, the amidinate ligand in $\mathbf{6}$ is only $\eta^{1}$-coordinated. Complexes $\mathbf{5}$ and $\mathbf{6}$ mediate the intermolecular hydrophosphination of styrene with primary $\left(\mathrm{PhPH}_{2}\right)$ and secondary $\left(\mathrm{HPPh}_{2}\right)$ phosphines. Their catalytic performance compares favourably with those of other barium precatalysts for these reactions. During the course of the hydrophosphination of styrene with $\mathrm{HPPh}_{2}$ catalysed by $\mathbf{5}$, the phosphide complex $\left[\left\{\mathrm{I}^{\wedge} \mathrm{A}^{\text {crown }}\right\} \mathrm{BaPPh}_{2}\right]$ (7) could be intercepted and crystallographically characterised.
\end{abstract}




\section{Introduction}

The past 15 years have experienced the emergence of main group metals molecular (pre)catalysts built on abundant metals as suitable alternatives to mainstream homogenous catalytic systems devised around late transition metals. Amongst these, the three large alkaline earths (= Ae) calcium, strontium and barium have been used to a great effect to fabricate a range of potent catalysts. ${ }^{1}$ Following the seminal works by the groups of Hill and Harder, $\mathrm{Ca}, \mathrm{Sr}$ and $\mathrm{Ba}$ complexes have been used to catalyse $\mathrm{C}-\mathrm{N}$ bond formation in the intramolecular ${ }^{2}$ and intermolecular ${ }^{3}$ hydroamination of alkenes. Effective alkene hydrosilylation mediated by Ae complexes has been known for 10 years. ${ }^{4}$ By comparison, Ae-promoted regiospecific C-P (alkene and alkyne ${ }^{6}$ hydrophosphination) and $\mathrm{N}-\mathrm{Si}$ (amine/hydrosilanes heterodehydrocouplings ${ }^{7}$ ) bond creations are recent addition to the arsenal of tools implementable by synthetic chemists.

Organophosphorus compounds find widespread applications, e.g. as ligands in coordination chemistry and for metal-catalysed organic transformations, ${ }^{8}$ in industry as pest control and pesticides, and also owing to their biological activity, e.g. such as antibiotics and antitumor agents. ${ }^{9}$ The $100 \%$ atom-efficient catalysed addition of $\mathrm{H}-\mathrm{P}$ bonds across unsaturated $\mathrm{C}=\mathrm{C}$ bonds is an attractive way to produce a variety of $\mathrm{C}-\mathrm{P}$ bonds. Across an homologous series of complexes of large Ae metals, barium alkene hydrophosphination precatalysts have displayed the most impressive performances, enabling addition of secondary phosphines across activated alkenes (vinylarenes, conjugated dienes) with high anti-Markovnikov regioselectivity and reaction rates. ${ }^{3 c, 3 d}$ It was found that reaction rates increase upon descending group according to $\mathrm{Ca}<\mathrm{Sr}<$ $\mathrm{Ba}$, a trend repeated on many occasions of Ae-catalysed reactions, ${ }^{3-7,10}$ albeit not systematically. ${ }^{2,7 a, 11}$

The design of bulky, monoanionic ligand $\left(=\{\mathrm{Lig}\}^{-}\right)$capable of sheltering the large, electropositive and polarisable $\mathrm{Ae}^{2+}$ ions $\left(r_{\text {ionic }}: \mathrm{Ca}^{2+}, 1.00 \AA\right.$; $\mathrm{Sr}^{2+}, 1.18 \AA$; $\mathrm{Ba}^{2+}, 1.35 \AA$ ) has been key to the implementation of Ae-mediated catalysis. In particular, heteroleptic precatalysts of the type $\{\mathrm{Lig}\} \mathrm{AeX}$ (where $\mathrm{X}^{-}=$ $\mathrm{N}\left(\mathrm{SiMe}_{2} \mathrm{H}\right)_{2}{ }_{2}, \mathrm{~N}\left(\mathrm{SiMe}_{3}\right)_{2}{ }_{2}, \mathrm{CH}\left(\mathrm{SiMe}_{3}\right)_{2}{ }^{-}, \mathrm{PPh}_{2}{ }^{-}$, etc. $)$provide on the whole the best versatility and turnovers. ${ }^{1}$ In this context, nitrogen-based ligands have had the upper hand. ${ }^{1,12}$ Most prominently, the $\beta$-diketiminate $\left\{\mathrm{BDI}^{\text {Dipp2 }}\right\}^{-}\left(\right.$where BDI ${ }^{\text {Dipp2 }}=\mathrm{CH}\left[\mathrm{C}\left(\mathrm{CH}_{3}\right) \mathrm{NDipp}_{2}, \mathrm{Dipp}=2,6\right.$-diisopropylphenyl, Figure 1 ) has been most useful, affording access to unusual or highly reactive low coordinate Ae species such as the ubiquitous $\left[\left\{\mathrm{BDI}^{\mathrm{Dipp} 2}\right\} \mathrm{CaN}\left(\mathrm{SiMe}_{3}\right)_{2}\right.$.(thf) $]$ (1) and its derivatives with smaller $\mathrm{X}^{-}$functionalities. ${ }^{1-7,13}$ Related $\left[\left\{\mathrm{I}^{\wedge} \mathrm{A}^{\text {Dipp2}}\right\} \mathrm{AeX} .(\text { thf })_{n}\right]$ complexes $\left(\mathrm{X}^{-}=\mathrm{N}\left(\mathrm{SiMe}_{3}\right)_{2}{ }^{-}\right.$or $\mathrm{CH}\left(\mathrm{SiMe}_{3}\right)_{2}{ }^{-}, n=1-2$ Figure 1$)$ incorporating the hindered iminoanilide $\left\{\mathrm{I}^{\wedge} \mathrm{A}^{\text {Dipp } 2}\right\}^{-}$are excellent hydroamination and hydrophosphination precatalysts, especially for $\mathrm{Ae}=\mathrm{Ba}(\mathbf{2}) .^{3 c, 3 d}$ Besides, amidinates have been shown to constitute suitable ligand platforms for the synthesis of original heteroleptic Ae complexes, e.g. molecular hydrides as in 3. ${ }^{14}$ Elsewhere, the utilisation of multidentate neutral (co)ligands such as polyamines and aza-crown-ethers has also yielded very active Ae hydrides hydrogenation catalysts $^{4 b, 15}$ and various Ae polymerisation catalysts, e.g. $\left[\left\{\mathrm{LO}^{\mathrm{NO} 4}\right\} \mathrm{BaN}\left(\mathrm{SiMe}_{2} \mathrm{H}\right)_{2}\right](4)$ bearing the multidentate aza-crown-ether-phenolate $\left\{\mathrm{LO}^{\mathrm{NO} 4}\right\}^{-} .^{10 a, 16}$ 


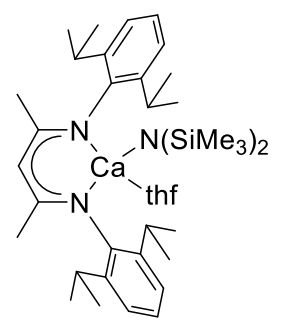

$(1)^{2 a}$

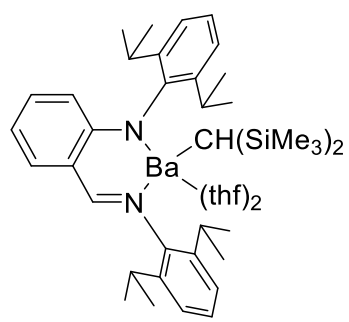

$(2)^{3 d}$

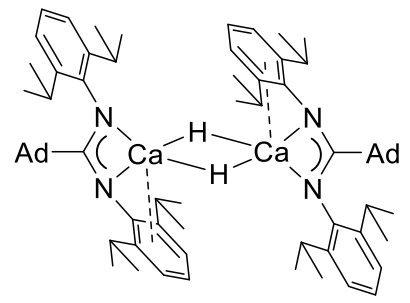

$(3)^{14 a}$

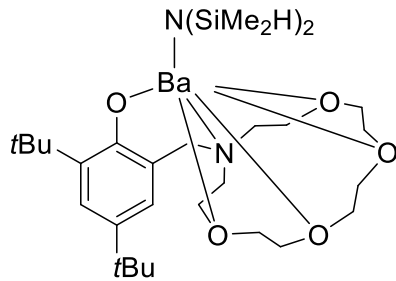

$(4)^{16}$

Fig. 1 Examples of $N$-based and macrocycle-functionalised alkaline earth molecular complexes. Ad = adamantyl.

As part of our ongoing studies in the area of Ae-mediated molecular catalysis, we thought of combining the advantages of $\mathrm{N}$-based ligands and macrocycles into ligand frameworks able to stabilise barium species. We report here on the design of new bulky iminoaniline and amidine proligands that include a tethered macrocycle. We anticipated that the pairing of bulky iminoanilide or amidinate, which have shown their ability to kinetically stabilise Ae complexes against ligand scrambling, with a macrocycle known for its ability to stabilise otherwise electronically unsaturated Ae species, would deliver original ligands particularly well suited to this chemistry. These ligands were used to generate heteroleptic barium amido complexes that in turn display good performance in the hydrophosphination of vinylarenes. Synthetic, structural and catalytic features of these barium compounds are discussed.

\section{Results and Discussion}

\section{Synthesis and characterisation}

The functionalised iminoaniline $\left\{\mathrm{I}^{\wedge} \mathrm{A}^{\text {crown }}\right\} \mathrm{H}$ and amidine $\left\{\mathrm{Am}^{\text {crown }}\right\} \mathrm{H}$ proligands containing a tethered 15member macrocycle were constructed in convergent multistep syntheses (Scheme 1) that started with the large scale synthesis of 2-(1-aza-15-crown-5)-ethan-1-amine (A). Condensation of A with the Dipp- $N$ substituted benzaldehyde $\mathbf{B}$ afforded $\left\{\mathrm{I}^{\wedge} \mathrm{A}^{\text {crown }}\right\} \mathrm{H}$, whereas $\left\{\mathrm{Am}^{\text {crown }}\right\} \mathrm{H}$ was obtained by reacting $\mathbf{A}$ with the adamantyl-substituted $N$-Dipp-carbimidoyl chloride C. Complete experimental details for the synthesis of the two proligands and of the synthetic intermediates, together with pertaining analytical data, are provided in the Supporting Information. ${ }^{\#}$ Note that the condensation affording $\left\{\mathrm{I}^{\wedge} \mathrm{A}^{\text {crown }}\right\} \mathrm{H}$, aka step (xiv) in Scheme 1 , requires several days and addition of amine $\mathbf{A}$ in several portions. Under optimised conditions, this proligand was ultimately obtained in high yield as an off-white oil which solidified slowly upon standing at room temperature. However, we found that the final yields of isolated product could vary to noticeable extents depending on reaction times and protocol for the addition of $\mathbf{A}$. 

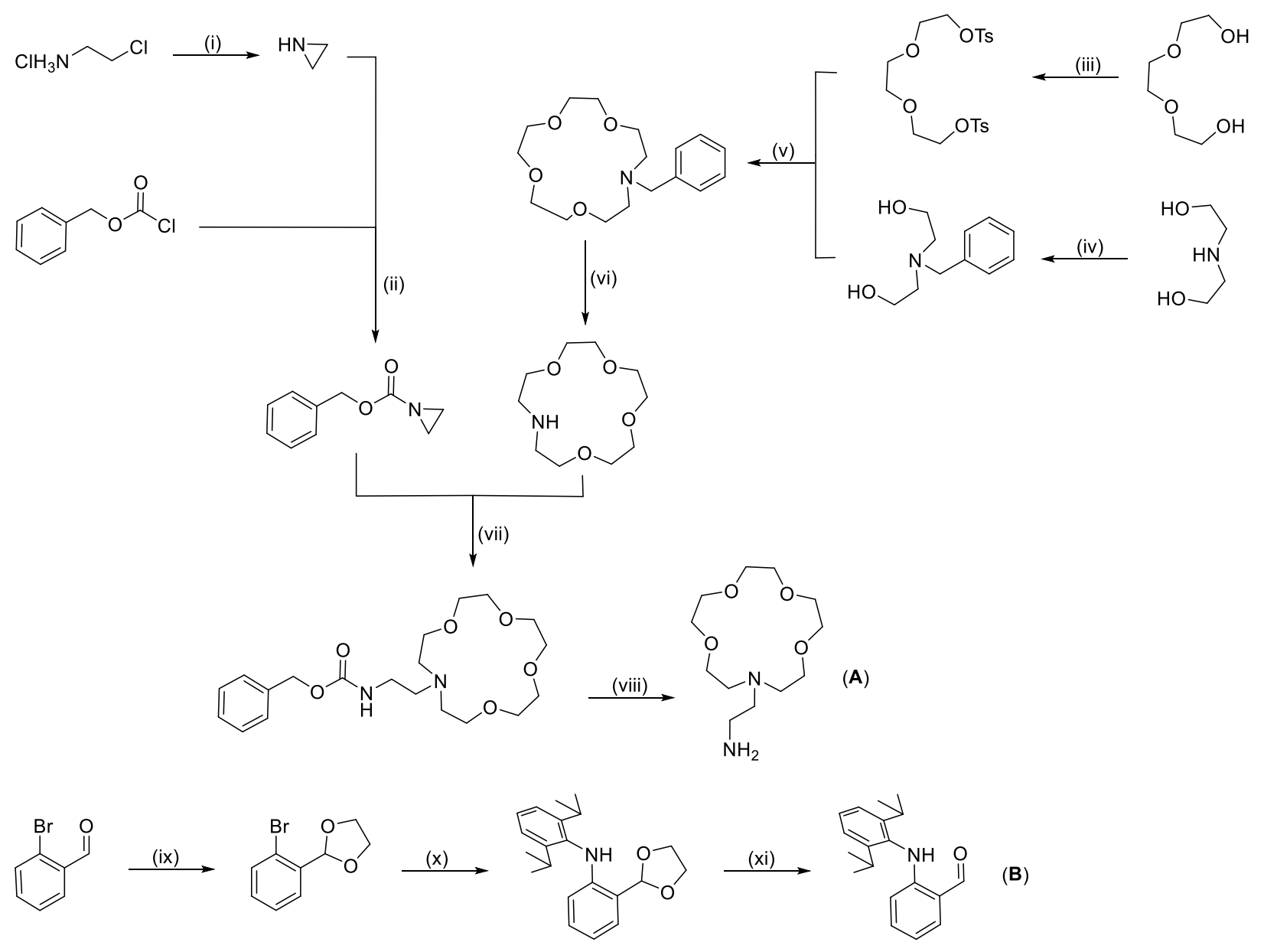

(B)
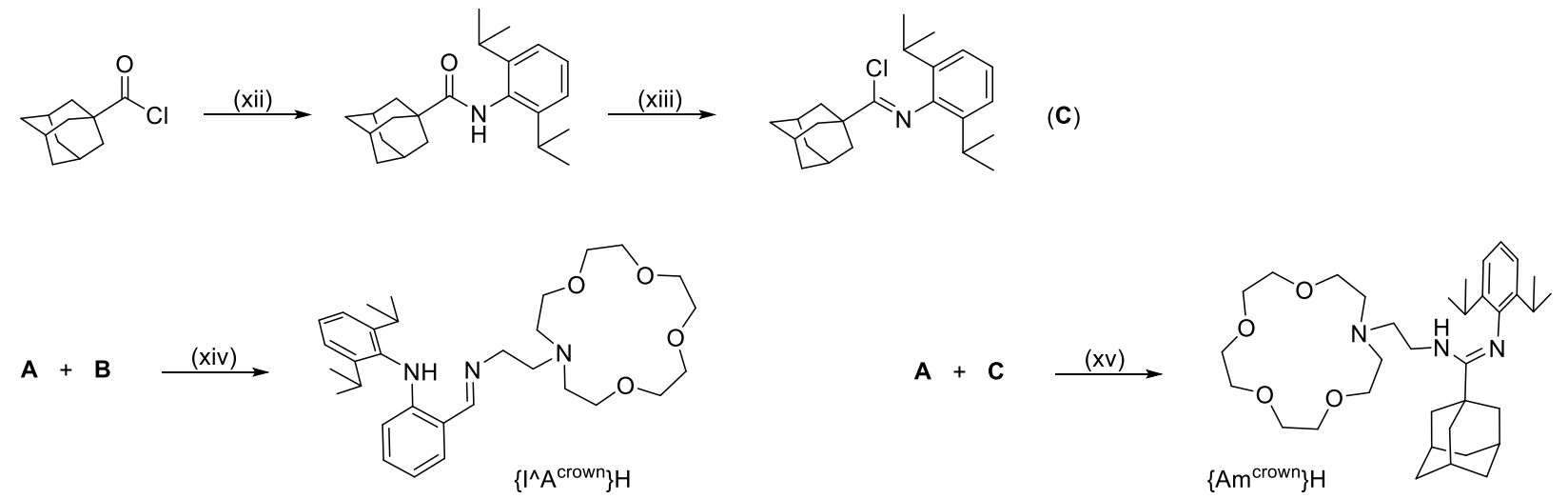

Scheme 1. Synthesis of the proligands $\left\{\mathrm{I}^{\wedge} \mathrm{A}^{\text {crown }}\right\} \mathrm{H}$ and $\left\{\mathrm{Am}^{\text {crown }}\right\} \mathrm{H}$. Reaction conditions: (i) $\mathrm{NaOH}, \mathrm{H}_{2} \mathrm{O}, 50{ }^{\circ} \mathrm{C}, 4 \mathrm{~h}$, 75\%; (ii) $\mathrm{Et}_{2} \mathrm{O}, \mathrm{NEt}_{3}, 0$ to $20^{\circ} \mathrm{C}, 12 \mathrm{~h}, 51 \%$; (iii) $\mathrm{TsCl}, \mathrm{DMAP}, \mathrm{NEt}_{3}, \mathrm{CH}_{2} \mathrm{Cl}_{2}, 0$ to $20{ }^{\circ} \mathrm{C}, 12 \mathrm{~h}, 85 \%$; (iv) $\mathrm{BnBr}$, $\mathrm{Na}_{2} \mathrm{CO}_{3}$, acetone, reflux, $4 \mathrm{~h}, 80 \%$; (v) $\mathrm{NaOH}, n \mathrm{Bu} 4 \mathrm{NBr}$, toluene, $70{ }^{\circ} \mathrm{C}, 10 \mathrm{~h}, 82 \%$; (vi) $\mathrm{H}_{2}, \mathrm{Pd} / \mathrm{C}, \mathrm{MeOH}, 20{ }^{\circ} \mathrm{C}, 12$ h, 80\%; (vii) $\mathrm{CH}_{3} \mathrm{CN} /$ toluene (1:1 v/v), reflux, $24 \mathrm{~h}, 70 \%$; (viii) $\mathrm{H}_{2}, \mathrm{Pd} / \mathrm{C}, \mathrm{MeOH}, 20{ }^{\circ} \mathrm{C}, 15 \mathrm{~h}, 97 \%$; (ix) $\mathrm{HOCH}_{2} \mathrm{CH}_{2} \mathrm{OH}$, PTSA, toluene, reflux, 48 h, 61\%; (x) 2,6-i $\mathrm{Pr}_{2} \mathrm{C}_{6} \mathrm{H}_{3} \mathrm{NH}_{2}, \mathrm{Pd}(\mathrm{OAc})_{2}, t \mathrm{BuOK}, \mathrm{P} t \mathrm{Bu} 3$, thf, reflux, 16 h; (xi) $\mathrm{CF}_{3} \mathrm{COOH}, \mathrm{MeOH}, 1 \mathrm{~h}, 20{ }^{\circ} \mathrm{C}, 38 \%$; (xii) 2,6-i $\mathrm{Pr}_{2} \mathrm{C}_{6} \mathrm{H}_{3} \mathrm{NH}_{2}$, toluene, $\mathrm{NEt}_{3}, 70{ }^{\circ} \mathrm{C}, 3 \mathrm{~h}, 98 \%$; (xiii) $\mathrm{SOCl}_{2}$, reflux, $3 \mathrm{~h}, 90 \%$; (xiv) petroleum ether, reflux, $10 \mathrm{~d}$, 90\%; (xv) $\mathrm{NEt}_{3}, \mathrm{CH}_{2} \mathrm{Cl}_{2}, 20^{\circ} \mathrm{C}, 72 \mathrm{~h}, 32 \%$. 
The sterically congested amidine $\left\{\mathrm{Am}^{\text {crown }}\right\} \mathrm{H}$ was isolated as analytically pure pale yellow crystals in non-optimised ca. 30\% yield by reaction of compounds $\mathbf{A}$ and $\mathbf{C}$ under mild and straightforward operating conditions (see Scheme 1). Alternatively, it was obtained in 70-80\% yield as an oily material, although NMR analysis showed in these cases the presence of trace amounts of residual impurities. Both proligands were fully characterised by NMR, mass spectrometry and combustion analyses. They are highly soluble in all common organic solvents, including aliphatic hydrocarbons. Single crystals of $\left\{\mathrm{I}^{\wedge} \mathrm{A}^{\text {crown }}\right\} \mathrm{H}$ suitable for $\mathrm{X}$-ray diffraction crystallography were grown from the oily material upon standing at room temperature. Its molecular solid-state structure, with notable interatomic distances, are given in Figure 2. Crystals of $\left\{\mathrm{Am}^{\text {crown }}\right\} \mathrm{H}$ were also analysed, but the final refinement of the structure was high $(>20 \%)$ due to high disorder.

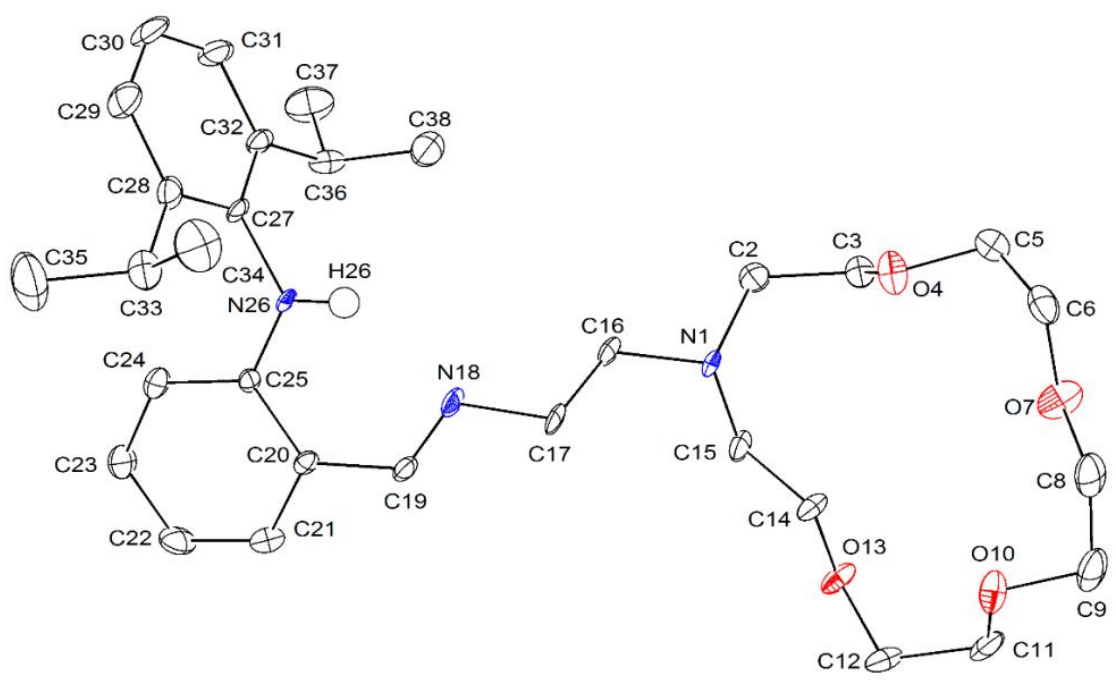

Fig. 2. ORTEP representation of the molecular solid-state structure of $\left\{I^{\wedge} A^{\text {crown }}\right\} H$. Ellipsoids at the $50 \%$ probability level. Only one of the two identical molecules in the asymmetric unit is depicted. $\mathrm{CH}$ atoms omitted for clarity. Selected interatomic distances $(\AA)$ : C17-N18 = 1.461(4), N18-C19 = 1.268(4), N1-C16 = 1.458(3), N1-C15 = 1.469(4), N1-C2 $=1.470(4), \mathrm{C} 25-\mathrm{N} 26=1.369(4), \mathrm{N} 26-\mathrm{C} 27=1.428(4)$.

The amido group $\mathrm{N}\left(\mathrm{SiMe}_{2} \mathrm{H}\right)_{2}^{-}$has been introduced in barium chemistry as a useful tool for the stabilisation of barium complexes through the presence of intramolecular $\mathrm{Ba} \cdots \mathrm{H}-\mathrm{Si}$ anagostic interactions, as in a monometallic aminoether-phenolato complex $\left[\left\{\mathrm{LO}^{\mathrm{NO} 4}\right\} \mathrm{BaN}\left(\mathrm{SiMe}_{2} \mathrm{H}\right)_{2}\right](3)^{16}$ or in the trinuclear cluster $\left[\mathrm{Ba} 3\left\{\mathrm{OSi}(\mathrm{O} t \mathrm{Bu})_{3}\right\}_{3}\left\{\mathrm{~N}\left(\mathrm{SiHMe}_{2}\right)_{2}\right\}_{3}\right] .{ }^{17}$ Following the same line, the stoichiometric reaction of $\left.\left[\mathrm{Ba}\left\{\mathrm{N}\left(\mathrm{SiMe}_{2} \mathrm{H}\right)_{2}\right\}_{2} \text {. (thf }\right)_{2}\right]$ with the iminoaniline $\left\{\mathrm{I}^{\wedge} \mathrm{A}^{\text {crown }}\right\} \mathrm{H}$ returned, upon selective release of one equivalent of $\left.\mathrm{HN}\left(\mathrm{SiMe}_{2}\right) \mathrm{H}\right)_{2}$, the heteroleptic complex $\left[\left\{\mathrm{I}^{\wedge} \mathrm{A}^{\text {crown }}\right\} \mathrm{BaN}\left(\mathrm{SiMe}_{2} \mathrm{H}\right)_{2}\right](\mathbf{5})$ as an orange solid in 
$86 \%$ yield (Scheme 2). The ${ }^{1} \mathrm{H}$ NMR spectrum of 5 in thf- $d_{8}$ is characterised by a singlet at $\delta 8.04$ ppm for the $\mathrm{CH}=\mathrm{N}$ imine hydrogen, and a multiplet at $\delta 4.57 \mathrm{ppm}$ for the $\mathrm{Si} H$ hydrogen. There is a substantial level of fluxionality in the complex, as the resonances for $\mathrm{OCH}_{2}, \mathrm{CH}\left(\mathrm{CH}_{3}\right)_{2}$ and $\mathrm{Si}\left(\mathrm{CH}_{3}\right)_{2}$ moieties are somewhat broad at room temperature. Similarly, the amidinate complex $\left[\left\{\mathrm{Am}^{\text {crown }}\right\} \mathrm{BaN}\left(\mathrm{SiMe}_{2} \mathrm{H}\right)_{2}\right](\mathbf{6})$ was isolated as colourless microcrystals in $85 \%$ yield following treatment of $\left[\mathrm{Ba}\left\{\mathrm{N}\left(\mathrm{SiMe}_{2} \mathrm{H}\right)_{2}\right\}_{2}\right]_{\infty}$ with one equivalent of $\left\{\mathrm{Am}^{\text {crown }}\right\} \mathrm{H}$ and release of $\mathrm{HN}\left(\mathrm{SiMe}_{2} \mathrm{H}\right)_{2}$. Complexes 5 and $\mathbf{6}$ are sparingly to moderately soluble in hydrocarbons (petroleum ether, benzene and toluene), and dissolve well in ethers. The presence of two stretching bands for $\mathrm{Si}-\mathrm{H}$ bonds at 2052 and $1990 \mathrm{~cm}^{-1}$ (for 5) and at 2014 and $1975 \mathrm{~cm}^{-1}$ (for 6) in the FTIR spectra of the two complexes recorded as Nujol mulls is consistent with $\mathrm{Ba} \cdots \mathrm{H}-\mathrm{Si}$ anagostic interactions in the solid state. This is corroborated by the ${ }^{1} \mathrm{H}$ NMR spectrum of 6 recorded in thf- $d_{8}$, where the ${ }^{1} J_{\mathrm{SiH}}$ coupling constant of $160 \mathrm{~Hz}$ is also diagnostic of mild $\mathrm{Ba}{ }^{\cdots} \mathrm{H}-\mathrm{Si}$ interactions in solution.
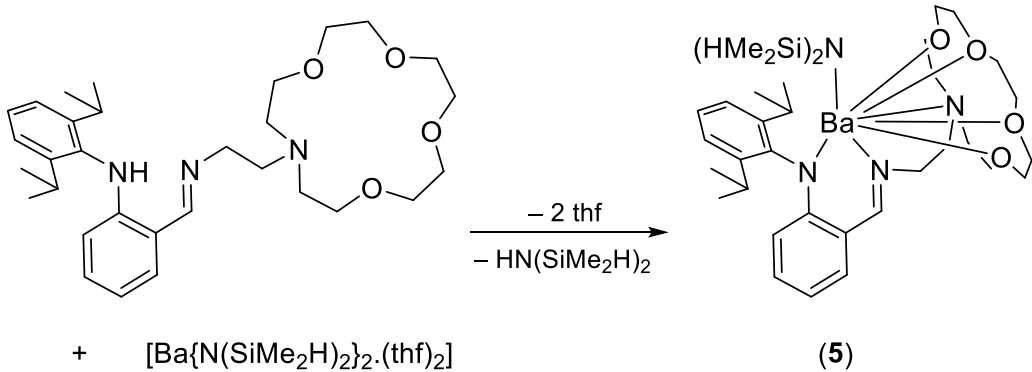

(5)
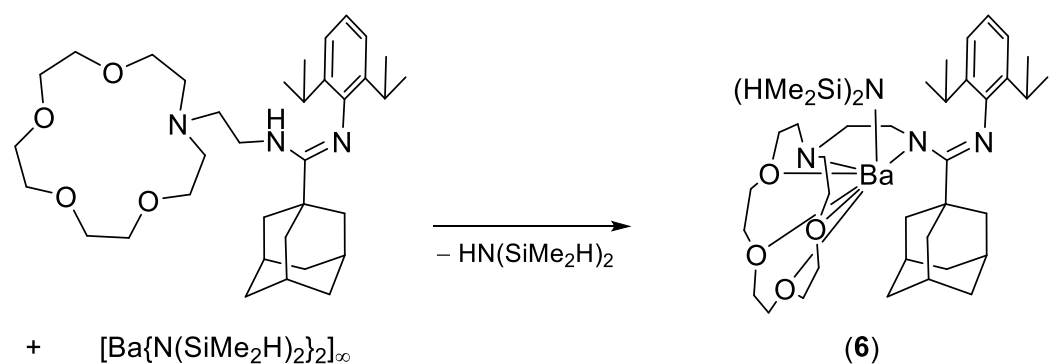

(6)

Scheme 2. Syntheses of $\left[\left\{\mathrm{I}^{\wedge} \mathrm{A}^{\text {crown }}\right\} \mathrm{BaN}\left(\mathrm{SiMe}_{2} \mathrm{H}\right)_{2}\right](\mathbf{5}),\left[\left\{\mathrm{Am}^{\text {crown }}\right\} \mathrm{BaN}\left(\mathrm{SiMe}_{2} \mathrm{H}\right)_{2}\right](\mathbf{6})$.

The molecular solid-state structure of $\mathbf{5}$ depicted in Figure 3 shows the complex to rest in an eightcoordinate environment, with coordination of all heteroatoms on the ancillary ligand onto the metal centre completed by the $\mathrm{N}_{\text {silazide }}$ atom from the tetramethyldisilazide co-ligand. The $\mathrm{Ba}-\mathrm{O}$ and $\mathrm{Ba}-\mathrm{N}_{\text {amine }}$ interatomic distances to the heteroatoms in the aza-crown-ether fragment are unremarkable and compare to those in the phenolato complex $\left[\{\mathrm{LO}\} \mathrm{BaN}\left(\mathrm{SiMe}_{2} \mathrm{H}\right)_{2}\right](3)$ already mentioned. ${ }^{16}$ Similarly, that $\mathrm{Ba}-\mathrm{N}_{\text {silazide }}$ bond length in 5 (2.704(3) $\AA$ ) matches that in 3 (2.688(2) $\AA$ ). Coordination of the $\mathrm{N}_{\text {imine }}$ atom onto barium does not 
induce a significant stretching of the $\mathrm{C}=\mathrm{N}$ bond compared to that in the proligand (1.287(5) $\AA$ in $\mathbf{5}$ and 1.268(4) $\AA$ in the proligand). Complex 5 exhibits a mild $\mathrm{Ba} \cdots \mathrm{H}-\mathrm{Si}$ anagostic interaction with $\mathrm{H} 2_{\mathrm{Si}}{ }^{18}$ as indicated by the large discrepancy between the narrow Ba1-N4-Si2 and wider Ba1-N4-Si1 angles (104.90(14) and $126.02(16)^{\circ}$, respectively); this is consistent with the solution ${ }^{1} \mathrm{H}$ NMR data of the complex (see above). The barium atom protrudes greatly (1.76 $\AA$ ) out of the mean plane formed by the atoms $\mathrm{N} 2$, $\mathrm{C} 13, \mathrm{C} 14, \mathrm{C} 19$ and N3. Note that there is a substantial distortion of the aromatic ring in the anilido fragment, and that the iminoanilido core made of these six carbons atoms together with C13, N2 and N3 deviates very clearly from the planarity observed in the proligand (Figure 3).
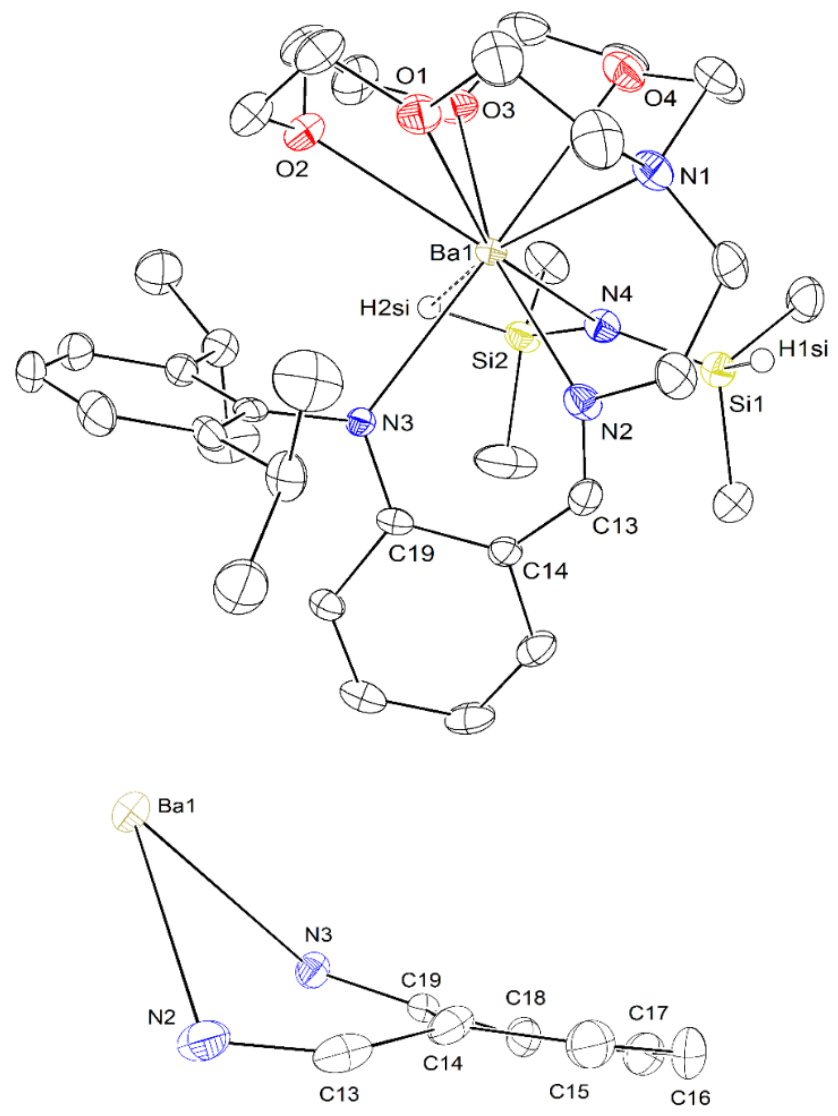

Fig. 3. Top, ORTEP representation of the molecular solid-state structure of $\left[\left\{\mathrm{I}^{\wedge} \mathrm{A}^{\text {crown }}\right\} \mathrm{BaN}\left(\mathrm{SiMe}_{2} \mathrm{H}\right)_{2}\right](\mathbf{5})$; bottom, representation of the non-planar iminoanilide core in the molecular solid-state structure of $\mathbf{5}$. Ellipsoids at the $50 \%$ probability level. $\mathrm{CH}$ atoms omitted for clarity. Selected interatomic distances $(\AA)$ and angles $\left({ }^{\circ}\right)$ : Ba1-N1 = 3.025(3), Ba1-N2 $=2.746(3)$, Ba1-N3 $=2.756(3)$, Ba1-N4 $=2.704(3), \mathrm{Ba} 1-\mathrm{O} 1=2.934(3), \mathrm{Ba} 1-\mathrm{O} 2=2.849(3), \mathrm{Ba} 1-\mathrm{O} 3=$ 2.906(3), Ba1-O4 = 2.928(3), N2-C13 = 1.287(5), N2-C12 = 1.461(5); Si1-N4-Ba1 = 126.02(16), Si2-N4-Ba1 = 104.90(14). 
The molecular structure of complex 6 is given in Figure 4; it shows one of the two distinct but very similar molecules of the complex found in the asymmetric unit. The final refinement $\left(R_{1}=16.4 \%\right)$ for the structure is insufficient to enable a thorough discussion of the metric parameters, but the connectivity in the solid state could be established without ambiguity. The barium atom is seven-coordinate, with binding of all heteroatoms in the aza-crown-ether fragment completed by the nitrogen atom of tetramethylsilazide (N1) and, remarkably, by only one of the $\mathrm{N}$ atoms (N33) in the hence $\eta^{1}$-coordinated amidinate; the other $\mathrm{N}$ atom (N35) points away from the metal centre.

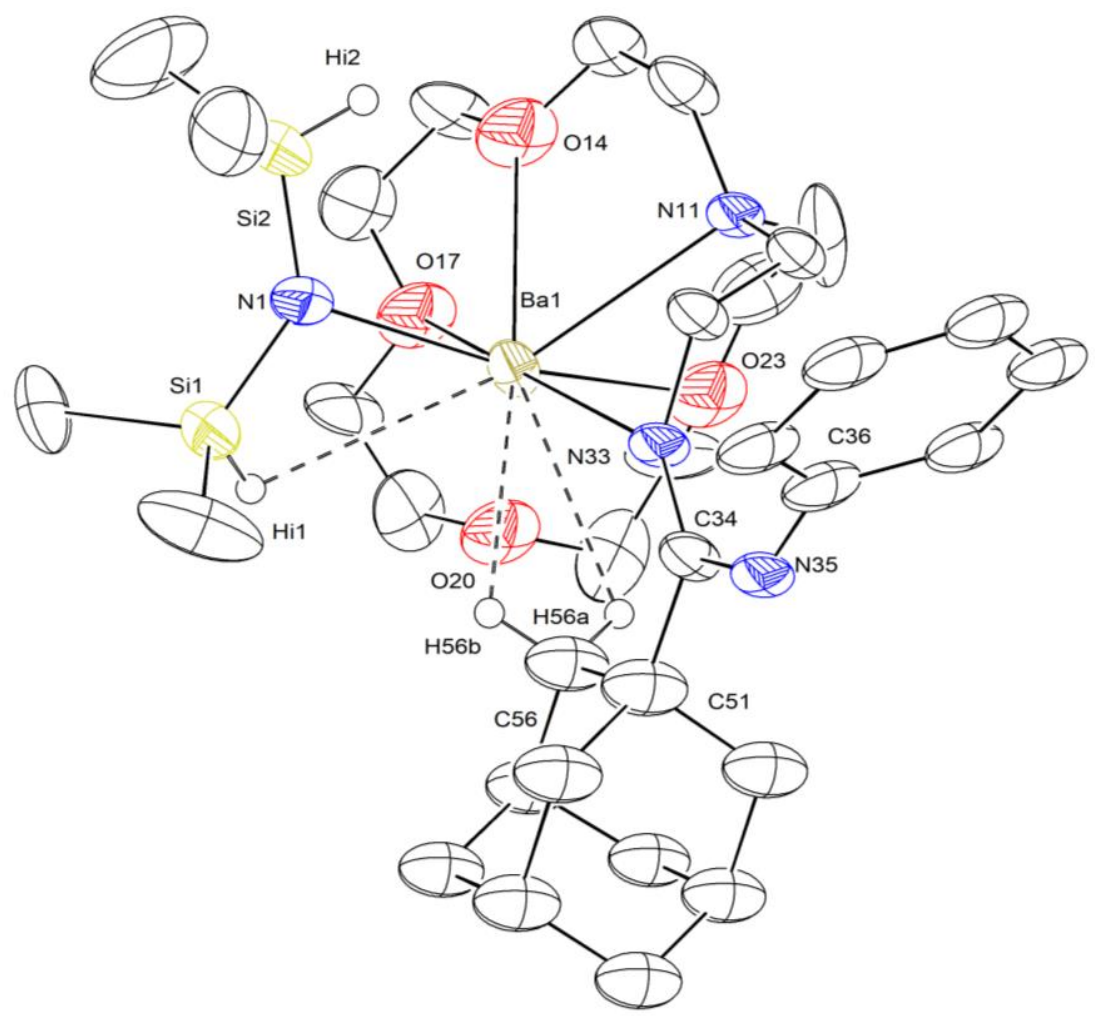

Fig. 4. ORTEP representation of the molecular solid-state structure of $\left[\left\{\mathrm{Am}^{\text {crown }}\right\} \mathrm{BaN}\left(\mathrm{SiMe}_{2} \mathrm{H}\right)_{2}\right](6)$. Only one of the two molecules in the asymmetric unit is represented. Ellipsoids at the $50 \%$ probability level. Non-interacting benzene molecules, $i \mathrm{Pr}$ groups and $\mathrm{H}$ atoms other than those interactions with barium omitted for clarity. Poor refinement $\left(R_{1}\right.$ $=16.4 \%)$ precludes a thorough discussion of metric parameters.

Note that counter-intuitively, the distance from the central carbon atom C34 to the metal-bound nitrogen atom N33 (ca. $1.33 \AA$ ) seems shorter than that to the non-coordinating one N35 (ca. $1.40 \AA$ ), but the poor refinement of the data set precludes a detailed analysis. The $\eta^{1}$-coordination mode observed for the amidinate in $\mathbf{6}$ is unusual. A similar one was observed in calcium-hydride amidinates, but these complexes featured an additional pattern of stabilising $\mathrm{Ca} \cdots \mathrm{C}(\pi)$ interactions involving the flanking 2,6-i $\operatorname{Pr}_{2} \mathrm{C}_{6} \mathrm{H}_{3}$ substituents. ${ }^{12 e}$ There is no such interaction in 6. On the other hand, the geometrical features of the 
tetramethyldisilazide group, notably the largely different Ba1-N1-Si1 (ca. $106^{\circ}$ ) and Ba1-N1-Si2 (ca. 120 $\left.{ }^{\circ}\right)$ angles, militate in favour of the presence of a Ba1 $\cdots \mathrm{Hi1} \beta-\mathrm{Si}-\mathrm{H}$ anagostic interaction with Hi1.,.$^{3,16,17,19}$ Interestingly, the adamantyl substituent of the amidinate is directed towards the metal, and the short distances to the two hydrogen atoms H56a and H56b (ca. $2.80 \AA$ ) could indicate additional agostic bonding.

\section{Barium-catalysed intermolecular hydrophosphination of vinylarenes}

The catalytic performances of $\left[\left\{\mathrm{I}^{\wedge} \mathrm{A}^{\text {crown }}\right\} \mathrm{BaN}\left(\mathrm{SiMe}_{2} \mathrm{H}\right)_{2}\right](\mathbf{5})$ and $\left[\left\{\mathrm{Am}^{\text {crown }}\right\} \mathrm{BaN}\left(\mathrm{SiMe}_{2} \mathrm{H}\right)_{2}\right](\mathbf{6})$ in styrene hydrophosphination were examined in the light of earlier benchmark results obtained in our group for this catalysis. ${ }^{3 d, 5 d}$ Two reactions were initially examined (Scheme 3), involving the secondary phosphine $\mathrm{HPPh}_{2}$ (the archetypal substrate in intermolecular hydrophosphination catalysis) and the primary phosphine $\mathrm{PhPH}_{2}$.

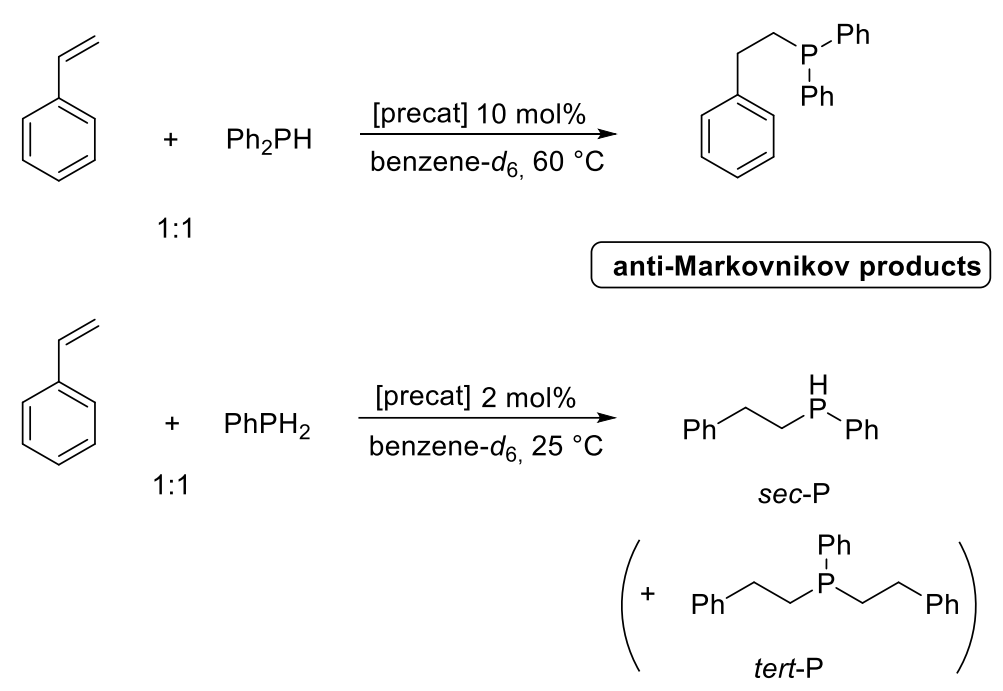

Scheme 3. Anti-Markovnikov hydrophosphination of styrene with $\mathrm{HPPh}_{2}$ or $\mathrm{PhPH}_{2}$ using $\left[\left\{\mathrm{I}^{\wedge} \mathrm{A}^{\text {crown }}\right\} \mathrm{BaN}\left(\mathrm{SiMe}_{2} \mathrm{H}\right)_{2}\right.$ (5) as the precatalyst.

A preliminary assessment in the equimolar hydrophosphination of styrene with $\mathrm{HPPh}_{2}$ (Scheme 3, top) showed that under otherwise identical experimental conditions ([styrene $]_{0} /\left[\mathrm{HPPh}_{2}\right]_{0} /[\mathrm{Ba}]_{0}=10: 10: 1$, benzene- $\left.d_{6}, 60{ }^{\circ} \mathrm{C}, 60 \mathrm{~min}\right)$, complexes $5\left(52 \%\right.$ conversion, TOF $\left.=0.5 \mathrm{~h}^{-1}\right)$ and $6(49 \%$ conversion, $\mathrm{TOF}=$ $\left.0.5 \mathrm{~h}^{-1}\right)$ both improve on the iminoanilide precatalyst $\left.\left[\left\{\mathrm{I}^{\wedge} \mathrm{A}^{\mathrm{Dipp} 2}\right\} \mathrm{BaN}\left(\mathrm{SiMe}_{3}\right)_{2} \text {. (thf }\right)_{2}\right](32 \%$ conversion, TOF $=0.3 \mathrm{~h}^{-1}$ ) bearing two Dipp substituents reported previously by our group (Table 1). ${ }^{3 c, 3 d}$ In all cases, and characteristically for alkaline earth precatalysts, ${ }^{1}$ the reactions are regioselective and only afford the antiMarkovnikov addition product $\mathrm{PhCH}_{2} \mathrm{CH}_{2} \mathrm{PPh}_{2}\left(\delta_{31 \mathrm{P}}=-16.04 \mathrm{ppm}\right.$ in benzene- $d_{6}$ at $\left.60{ }^{\circ} \mathrm{C}\right)$; no trace of the branched product could be detected by NMR spectroscopy. Subsequent work focused on the somewhat more active and more soluble precatalyst 5. Monitoring of the consumption of $\mathrm{HPPh}_{2}$ during the reaction 
catalysed by 5 showed that it is zeroth-order on the concentration $\left[\mathrm{HPPh}_{2}\right]$. This is reminiscent of the behaviour already known for $\left.\left[\left\{\mathrm{I}^{\wedge} \mathrm{A}^{\mathrm{Dipp} 2}\right\} \mathrm{BaN}\left(\mathrm{SiMe}_{3}\right)_{2} \text {. (thf }\right)_{2}\right]$, and for which the following kinetic rate law was established: ${ }^{3 d}$

$$
\text { rate }=\mathrm{k} \cdot\left[\mathrm{HPPh}_{2}\right]^{0} \cdot[\text { styrene }]^{1} \cdot[\mathrm{Ba}]^{1}
$$

It is therefore probable that in hydrophosphination reactions catalysed by $\mathbf{5}$, the operative mechanism is identical to that with $\left.\left[\left\{\mathrm{I}^{\wedge} \mathrm{A}^{\mathrm{Dipp} 2}\right\} \mathrm{BaN}\left(\mathrm{SiMe}_{3}\right)_{2} \text {. (thf }\right)_{2}\right]$, with rate-limiting 2,1-insertion of the unsaturated $\mathrm{C}=\mathrm{C}$ bond in the $\mathrm{Ba}-\mathrm{PPh}_{2}$ bond of a catalytically active $\left[\left\{\mathrm{I}^{\wedge} \mathrm{A}^{\mathrm{Dipp} 2}\right\} \mathrm{BaPPh}_{2}\right]$ species (vide infra).

The rate of reactions catalysed by $\mathbf{5}$ increases substantially for reactions carried out without solvent. For instance, full conversion of 50 equivalents of $\mathrm{HPPh}_{2}$ and styrene vs 5 was quantitative at $60{ }^{\circ} \mathrm{C}$ within 15 min, corresponding to a TOF value $\geq 200 \mathrm{~h}^{-1}$. Complex 5 also mediates the regiospecific antiMarkovnikov hydrophosphination of styrene with $\mathrm{PhPH}_{2}$ (Scheme 3, bottom). The conversion of 50 equivalents of styrene and phosphine $\left([\text { styrene }]_{0} /\left[\mathrm{PhPH}_{2}\right]_{0} /[5]_{0}=50: 50: 1\right)$ performed at $25{ }^{\circ} \mathrm{C}$ in benzene$d_{6}$ is near-quantitative within 60 min. It yields the secondary phosphine $\mathrm{PhPHCH}_{2} \mathrm{CH}_{2} \mathrm{Ph}$ (doublet at $\delta_{31 \mathrm{P}}=$ $-52.41 \mathrm{ppm}$ in benzene- $d_{6}$ at $60{ }^{\circ} \mathrm{C}$ ) with high selectivity, as only traces of the tertiary phosphine $\mathrm{PhP}\left(\mathrm{CH}_{2} \mathrm{CH}_{2} \mathrm{Ph}\right)_{2}$ (singlet at $\left.\delta_{31 \mathrm{P}}=-24.09 \mathrm{ppm}\right)$ were detected by ${ }^{1} \mathrm{H}$ and ${ }^{31} \mathrm{P}$ NMR spectroscopy. The selectivity towards the secondary phosphine under these experimental conditions typically exceeds $95 \%$. Note that under identical experimental conditions ([styrene $]_{0} /\left[\mathrm{PhPH}_{2}\right]_{0} /[\mathbf{5}]_{0}=50: 50: 1,25{ }^{\circ} \mathrm{C}, 60 \mathrm{~min}$, $[\text { metal }]_{0}=11.5 \mathrm{mM}$ in benzene- $\left.d_{6}\right)$, the performance of $5\left(93 \%\right.$ conversion, TOF $\left.=54 \mathrm{~h}^{-1}\right)$ betters that displayed by the divalent rare-earth precatalysts $\left[\left\{\mathrm{LO}^{\mathrm{NO} 4}\right\} \mathrm{YbN}\left(\mathrm{SiMe}_{3}\right)_{2}\right]\left(74 \%\right.$ conversion, $\left.\mathrm{TOF}=37 \mathrm{~h}^{-1}\right)$ and $\left[\left\{\mathrm{LO}^{\mathrm{NO} 4}\right\} \mathrm{SmN}\left(\mathrm{SiMe}_{3}\right)_{2}\right]\left(63 \%\right.$ conversion, TOF $\left.=32 \mathrm{~h}^{-1}\right)$ supported by the multidentate aminoetherphenolate $\left\{\mathrm{LO}^{\mathrm{NO} 4}\right\}^{-}$(see Figure 1). ${ }^{5 d}$ Substrate conversion reaches near completion in the reaction of two equivalents of styrene vs $\mathrm{PhPH}_{2}$ catalysed by $\mathbf{5}$ ([styrene $]_{0} /\left[\mathrm{PhPH}_{2}\right]_{0} /[\mathbf{5}]_{0}=50: 25: 1,25{ }^{\circ} \mathrm{C}, 60 \mathrm{~min},[\mathbf{5}]_{0}=$ $8.0 \mathrm{mM}$ in benzene- $\left.d_{6}\right)$, and the formation of the tertiary phosphine $\mathrm{PhP}\left(\mathrm{CH}_{2} \mathrm{CH}_{2} \mathrm{Ph}\right)_{2}$ is then selective. 
Table 1. Comparative data for the hydrophosphination of styrene with $\mathrm{HPPh}_{2}$ and various $\mathrm{Ba}$ precatalysts.

\begin{tabular}{|c|c|c|c|}
\hline Precatalyst & {$[\text { styrene }]_{0} /\left[\mathrm{HPPh}_{2}\right]_{0} /[\mathrm{Ba}]_{0}$} & $\begin{array}{c}\text { Conversion }^{b} \\
{[\%]}\end{array}$ & $\begin{array}{l}\mathrm{TOF}^{c} \\
{\left[\mathrm{~h}^{-1}\right]}\end{array}$ \\
\hline$\left[\left\{\mathrm{I}^{\wedge} \mathrm{A}^{\text {crown }}\right\} \mathrm{BaN}\left(\mathrm{SiMe}_{2} \mathrm{H}\right)_{2}\right](\mathbf{5})$ & 10:10:1 & 52 & 0.52 \\
\hline$\left[\left\{\mathrm{Am}^{\text {crown }}\right\} \mathrm{BaN}\left(\mathrm{SiMe}_{2} \mathrm{H}\right)_{2}\right](\mathbf{6})$ & 10:10:1 & 49 & 0.49 \\
\hline$\left[\left\{\mathrm{I}^{\wedge} \mathrm{A}^{\mathrm{Dipp} 2}\right\} \mathrm{BaN}\left(\mathrm{SiMe}_{3}\right)_{2} \cdot(\mathrm{thf})_{2}\right]^{d}$ & 10:10:1 & 32 & 0.32 \\
\hline
\end{tabular}

On the nature of the active species in Ba-mediated intermolecular alkene hydrophosphination

During the course of the hydrophosphination of styrene with $\mathrm{HPPh}_{2}$ catalysed by 5 (see Scheme 3, top) carried out in bznezene- $d_{6}$ at $60{ }^{\circ} \mathrm{C}$, a small crop of orange single crystals formed out of solution. The identity of the compound, $\left[\left\{\mathrm{I}^{\wedge} \mathrm{A}^{\text {crown }}\right\} \mathrm{BaPPh}_{2}\right](7)$, was established by X-ray diffraction analysis.

The molecular structure of $\mathbf{7}$ shows the barium to rest in an eight-coordinate environment, with coordination of all heteroatoms form the macrocycle (Figure 5). To our knowledge, it is the first structurally authenticated heteroleptic barium-phosphide, although a number of homoleptic complexes have been previously reported, e.g. $\left[\left\{\left(\left[\mathrm{Me}{ }_{3} \mathrm{Si}\right]_{2} \mathrm{CH}\right)\left(\mathrm{C}_{6} \mathrm{H}_{3}-2-\mathrm{OMe}-3-\mathrm{Me}\right) \mathrm{P}\right\}_{2} \mathrm{Ba} .(\mathrm{thf})_{2}\right],{ }^{20}\left[\mathrm{Ba}\left\{\mathrm{P}\left(\mathrm{SiMe}_{3}\right)_{2}\right\}_{2} .(\mathrm{thf})_{4}\right],{ }^{21}$ $\left[\mathrm{Ba}\left(\mathrm{PPh}_{2}\right)_{2} \cdot(\text { thf })_{5}\right],{ }^{22}$ and $\left[\mathrm{Ba}\left(\mathrm{PPh}_{2}\right)_{2} \cdot\left(18\right.\right.$-crown-6)]. ${ }^{23}$ The $\mathrm{Ba}-\mathrm{N}$ interatomic distances in 7 are commensurate with those measured in the parent amido complex 5. The Ba-P bond length (3.3686(9) $\AA$ ) is comparable to those in $\left.\left[\mathrm{Ba}\left(\mathrm{PPh}_{2}\right)_{2} \text {. (thf }\right)_{5}\right]\left(3.328(2)\right.$ and 3.345(2) $\AA$ ) and $\left[\mathrm{Ba}\left(\mathrm{PPh}_{2}\right)_{2} .(18-\mathrm{crown}-6)\right]$ $(3.3484(7) \AA)^{22,23}$

The mononuclear complex $\mathbf{7}$ is thought to have formed under catalytic conditions upon deprotonation of the relatively acidic substrate $\mathrm{HPPh}_{2}$ by precatalyst $\mathbf{5}$, with concomitant release of $\mathrm{HN}\left(\mathrm{SiMe}_{2} \mathrm{H}\right)_{2}$. An NMR scale reaction between 5 and a stoichiometric amount of $\mathrm{HPPh}_{2}$ in thf- $d_{8}$ was consistent with the formation of a main new organometallics species assumed to be 7 (see ESI). Besides production of this new complex, the ${ }^{1} \mathrm{H}$ NMR spectrum indicated release of $\mathrm{HN}\left(\mathrm{SiMe}_{2} \mathrm{H}\right)_{2}$ and quantitative consumption of $\mathrm{HPPh}_{2}$, together with the presence a small amount, ca. $15 \%$, of free $\left\{\mathrm{I}^{\wedge} \mathrm{A}^{\text {crown }}\right\} \mathrm{H}$ (presumably released through hydrolysis during sample preparation). The ${ }^{31} \mathrm{P}$ NMR spectrum confirmed full consumption of $\mathrm{HPPh}_{2}(\delta$ ca. $-41 \mathrm{ppm}),{ }^{22}$ and a broad resonance at ca. $+5 \mathrm{ppm}$ compatible with a putative [Ba]- $\mathrm{PPh}_{2}$ species was detected. ${ }^{22-23}$ Yet, the NMR data for the reaction between $\mathbf{5}$ and $\mathrm{HPPh}_{2}$ also showed the presence of other unidentified species, and we failed to isolate analytically pure 7. Catalytic studies with pre-isolated 7 could hence not be conducted. We therefore cannot assert with total confidence that $\mathbf{7}$, which could not be isolated cleanly, is the sole active species under catalytic conditions. 


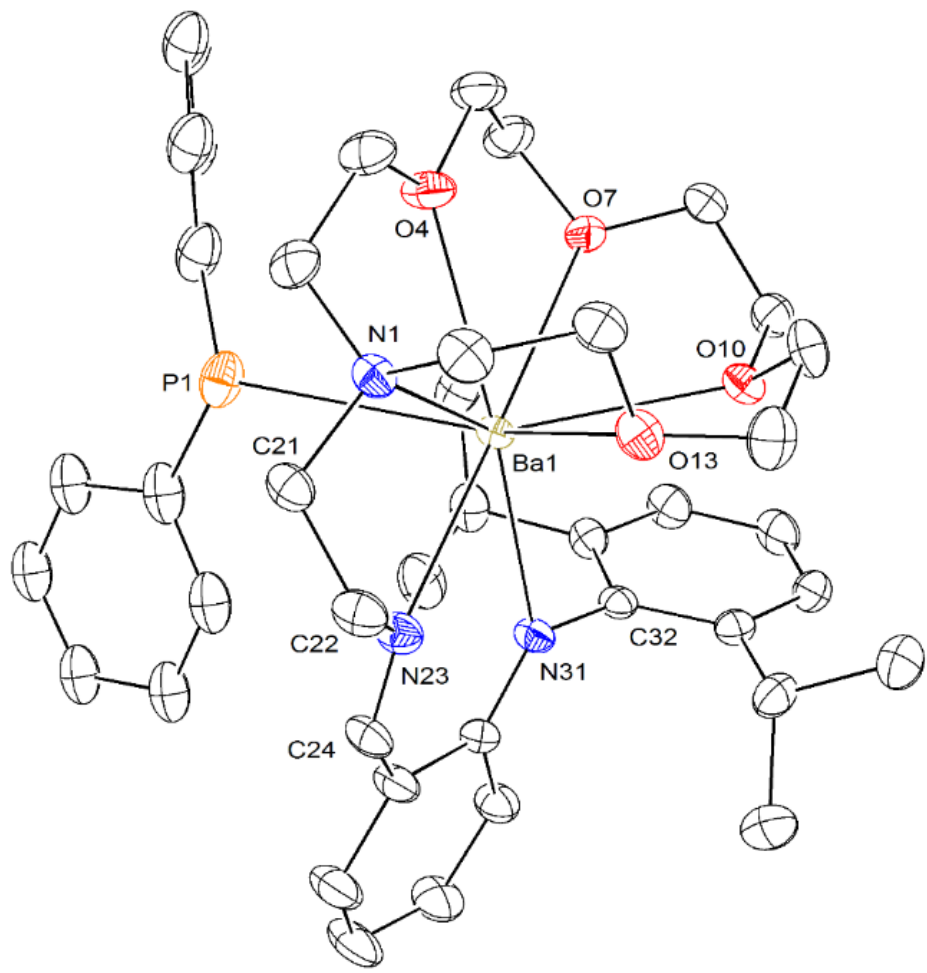

Fig. 5. ORTEP representation of the molecular solid-state structure of $\left[\left\{\mathrm{I}^{\wedge} \mathrm{A}^{\text {crown }}\right\} \mathrm{BaPPh}_{2}\right]$ (7). Ellipsoids at the $50 \%$ probability level. $\mathrm{H}$ atoms and non-interacting benzene molecule omitted for clarity. One component of each disordered $\mathrm{C}_{6} \mathrm{H}_{5}$ moieties is depicted. Selected interatomic distances $(\AA)$ : Ba1-N31 = 2.691(2), Ba1-N23 = 2.780(2), Ba1-O10 = 2.847(2), Ba1-O4 = 2.869(2), Ba1-O7 = 2.886(2), Ba1-O13 = 2.886(2), Ba1-N1 = 2.972(2), Ba1-C32 = 3.302(3), Ba1$\mathrm{P} 1=3.3686(9)$.

Based on our earlier investigations of the mechanism of intermolecular hydrophosphination reactions, ${ }^{3 d}$ 7 is thought to be the catalytically active species in the catalysed hydrophosphination of styrene mediated by 5 (Scheme 4). Considering that the reactions only generate the anti-Markovnikov products of addition, the mechanism is proposed to involve 2,1-insertion of the polarised $\mathrm{Ph}(\mathrm{H}) \mathrm{C}^{(\delta-)}=\mathrm{C}^{(\delta+)} \mathrm{H}_{2}$ double bond into the $[\mathrm{Ba}]-\mathrm{PPh}_{2}$ bond in 7 , resulting in the production of a transient barium alkyl species $[\mathrm{Ba}]-\mathrm{CH}(\mathrm{Ph}) \mathrm{CH}_{2} \mathrm{PPh}_{2}$. This intermediate is then rapidly protonated by an incoming $\mathrm{HPPh}_{2}$ to release the product $\mathrm{PhCH}_{2} \mathrm{CH}_{2} \mathrm{PPh}_{2}$ and regenerate the active species 7 . 


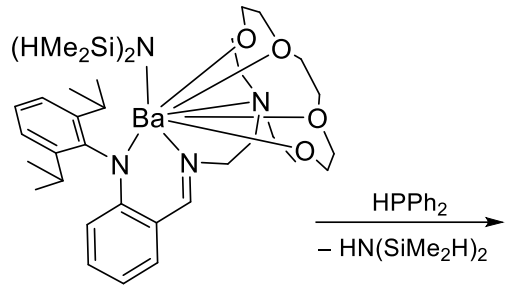

(5) precatalyst

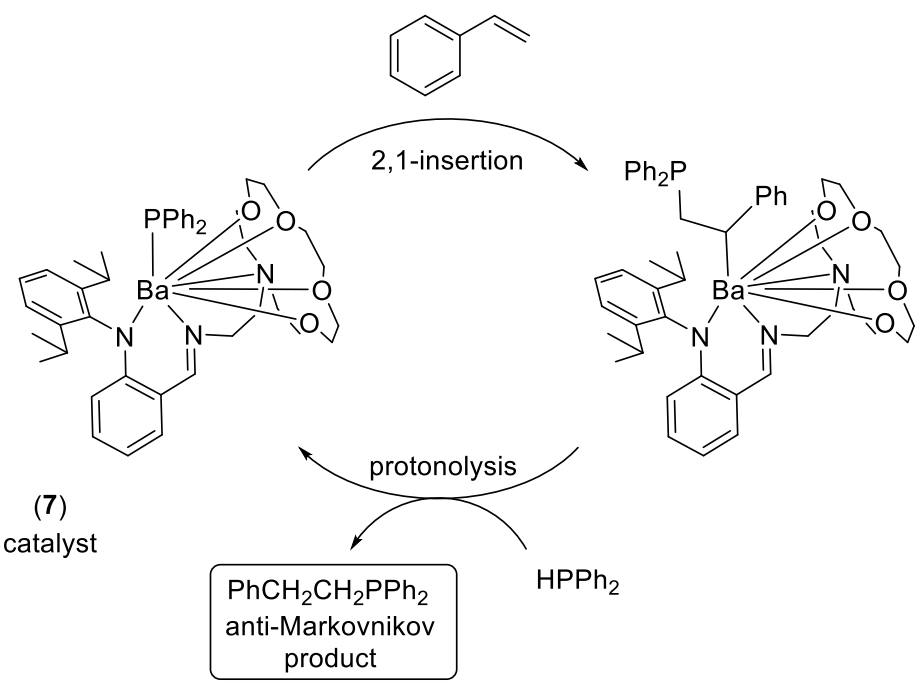

Scheme 4. Proposed mechanism for styrene/ $\mathrm{HPPh}_{2}$ hydrophosphination catalysed by $\left[\left\{\mathrm{I}^{\wedge} \mathrm{A}^{\text {crown }}\right\} \mathrm{BaN}\left(\mathrm{SiMe}_{2} \mathrm{H}\right)_{2}\right]$ (5).

\section{Conclusion}

The two nitrogen-based proligands $\left\{\mathrm{I}^{\wedge} \mathrm{A}^{\text {crown }}\right\} \mathrm{H}$ and $\left\{\mathrm{Am}^{\text {crown }}\right\} \mathrm{H}$, respectively an iminoaniline and an amidine bearing a tethered macrocycle side-arm prepared in multi-step procedures, enable the preparation of the heteroleptic barium complexes $\left[\left\{\mathrm{I}^{\wedge} \mathrm{A}^{\text {crown }}\right\} \mathrm{BaN}\left(\mathrm{SiMe}_{2} \mathrm{H}\right)_{2}\right]$ and $\left[\left\{\mathrm{Am}^{\text {crown }}\right\} \mathrm{BaN}\left(\mathrm{SiMe}{ }_{2} \mathrm{H}\right)_{2}\right]$. These solvent-free complexes have been characterised in the solid state, and they both exhibit high coordination numbers. The iminoanilide $\left[\left\{\mathrm{I}^{\wedge} \mathrm{A}^{\text {crown }}\right\} \mathrm{BaN}\left(\mathrm{SiMe}_{2} \mathrm{H}\right)_{2}\right]$ mediates competently the hydrophosphination of styrene with primary and secondary phosphines. These reactions exhibit entire anti-Markovnikov selectivity, and they also generate chemoselectively a single secondary phosphine in the reaction of $\mathrm{PhPH}_{2}$ with either one or two equivalents of styrene. 


\section{Conflicts of interest}

There are no conflicts of interest to declare.

\section{Notes and references}

* These two co-authors have contributed equally to the work.

\# Note that the macrocyclic 1-aza-15-crown-5, i.e. the product of reaction (vi) in Scheme 1, is commercially available, but at prohibitive cost for large scale syntheses.

1 (a) S. Harder, Chem. Rev., 2010, 110, 3852; (b) M. R. Crimmin and M. S. Hill, Top. Organomet. Chem., 2013, 45, 191; (c) M. S. Hill, D. J. Liptrot and C. Weetman, Chem. Soc. Rev., 2016, 45, 972.

2 (a) M. R. Crimmin, I. J. Casely and M. S. Hill, J. Am. Chem. Soc., 2005, 127, 2042; (b) M. R. Crimmin, M. Arrowsmith, A. G. M. Barrett, I. J. Casely, M. S. Hill and P. A. Procopiou, J. Am. Chem. Soc., 2009, 131, 9670; (c) M. Arrowsmith, M. R. Crimmin, A. G. M. Barrett, M. S. Hill, G. Kociok-Köhn and P. A. Procopiou, Organometallics, 2011, 30, 1493; (d) J. S. Wixey and B. D. Ward, Chem. Commun., 2011, 47, 5449; (e) B. Liu, T. Roisnel, J.-F. Carpentier and Y. Sarazin, Chem. Eur. J., 2013, 19, 2784; (f) N. Romero, S.-C. Roşca, Y. Sarazin, J.-F. Carpentier, L. Vendier, S. Mallet-Ladeira, C. Dinoi and M. Etienne, Chem. Eur. J., 2015, 21, 4115; (g) S. Tobisch, Chem. Eur. J., 2015, 21, 6765; (h) B. Freitag, C. A. Fischer, J. Penafiel, G. Ballmann, H. Elsen, C. Färber, D. F. Piesik and S. Harder, Dalton Trans., 2017, 46, 11192.

3 (a) A. G. M. Barrett, C. Brinkmann, M. R. Crimmin, M. S. Hill, P. Hunt and P. A. Procopiou, J. Am. Chem. Soc., 2009, 131, 12906; (b) C. Brinkmann, A. G. M. Barrett, M. S. Hill and P. A. Procopiou, J. Am. Chem. Soc., 2012, 134, 2193; (c) B. Liu, T. Roisnel, J.-F. Carpentier and Y. Sarazin, Angew. Chem. Int. Ed., 2012, 51, 4943; (d) B. Liu, T. Roisnel, J.-F. Carpentier and Y. Sarazin, Chem. Eur. J., 2013, 19, 13445; (e) S. Tobisch, Chem. Eur. J., 2014, 20, 8988.

4 (a) F. Buch, J. Brettar and S. Harder, Angew. Chem. Int. Ed., 2006, 45, 2741; (b) P. Jochmann, J. P. Davin, T. P. Spaniol, L. Maron and J. Okuda, Angew. Chem. Int. Ed., 2012, 51, 4452; (c) J. Intemann, H. Bauer, J. Pahl, L. Maron and S. Harder, Chem. Eur. J., 2015, 21, 11452.

5 See 2e, 3c, 3d and: (a) M. R. Crimmin, A. G. M. Barrett, M. S. Hill, P. B. Hitchcock and P. A. Procopiou, Organometallics, 2007, 26, 2953; (b) H. Hu and C. Cui, Organometallics, 2012, 31, 1208; (c) S.-C. Roşca, T. Roisnel, V. Dorcet, J.-F. Carpentier and Y. Sarazin, Organometallics, 2014, 33, 5630; (d) I. V. Basalov, B. Liu, T. Roisnel, A. V. Cherkasov, G. K. Fukin, J.-F. Carpentier, Y. Sarazin and A. A. Trifonov, Organometallics, 2016, 35, 3261; (e) B. J. Ward and P. A. Hunt, ACS Catal., 2017, 7, 459; (f) I. V. Lapshin, O. S. Yurova, I. V. Basalov, V. Yu. Rad'kov, E. I. Musina, A. V. Cherkasov, 
G. K. Fukin, A. A. Karasik and A. A. Trifonov, Inorg. Chem., 2018, 57, 2942; (g) I. V. Lapshin, I. V. Basalov, K. A. Lyssenko, A. V. Cherkasov and A. A. Trifonov, Chem. Eur. J., 2019, 25, 459.

6 (a) T. M. A. Al-Shboul, H. Görls and M. Westerhausen, Inorg. Chem. Commun., 2008, 11, 1419; (b) T. M. A. Al-Shboul, H. Görls, S. Krieck and M. Westerhausen, Eur. J. Inorg. Chem., 2012, 5451; (c) F. M. Younis, S. Krieck, T. M. A. Al-Shboul, H. Görls and M. Westerhausen, Inorg. Chem., 2016, 55, 4676.

7 (a) M. S. Hill, D. J. Liptrot, D. J. MacDougall, M. F. Mahon and T. P. Robinson, Chem. Sci., 2013, 4, 4212; (b) C. Bellini, J.-F. Carpentier, S. Tobisch and Y. Sarazin, Angew. Chem. Int. Ed., 2015, 54, 7679.

8 O. I. Kolodiazhnyi, Top. Curr. Chem., 2015, 360, 161.

9 D. Georgiadis and V. Dive, Top. Curr. Chem., 2015, 360, 1; (b) D. Virieux, J.-N. Volle, N. Bakalara and J.-L. Pirat, Top. Curr. Chem., 2015, 360, 39; (c) A. J. Wiemer and D. F. Wiemer, Top. Curr. Chem., 2015, 360, 115.

10 (a) Y. Sarazin, B. Liu, T. Roisnel, L. Maron and J.-F. Carpentier, J. Am. Chem. Soc., 2011, 133, 9069;

(b) H. Bauer, M. Alonso, C. Fischer, B. Rösch, H. Elsen and S. Harder, Angew. Chem. Int. Ed., 2018, $\mathbf{5 7 ,} 15177$.

11 M. Arrowsmith, M. S. Hill and G. Kociok-Köhn, Organometallics, 2010, 29, 4203.

12 (a) M. H. Chisholm, J. Gallucci and K. Phomphrai, Chem. Commun., 2003, 48; (b) S. Datta, M.T. Gamer and P. W. Roesky, Organometallics, 2008, 27, 1207; (c) T. D. Nixon and B. D. Ward, Chem. Commun., 2012, 48, 11790; (d) M. Arrowsmith, M. S. Hill and G. Kociok-Köhn, Organometallics, 2014, 33, 206; (e) A. Causero, G. Ballmann, J. Pahl, H. Zijlstra, C. Färber and S. Harder, Organometallics, 2016, 35, 3350; ( $f$ ) X. Shi, C. Hou, C. Zhou, Y. Song and J. Cheng, Angew. Chem. Int. Ed., 2017, 56, 16650.

13 (a) S. Harder and J. Brettar, Angew. Chem. Int. Ed., 2006, 45, 3474; (b) C. Ruspic, S. Nembenna, A. Hofmeister, J. Magull, S. Harder and H. W. Roesky, J. Am. Chem. Soc., 2006, 128, 15000; (c) C. Ruspic and S. Harder, Inorg. Chem., 2007, 46, 10426; (d) S. Nembenna, H. W. Roesky, S. Nagendran, A. Hofmeister, J. Magull, P.-J. Wilbrandt and M. Hahn, Angew. Chem. Int. Ed., 2007, 46, 2512; (e) A. S. S. Wilson, M. S. Hill, M. F. Mahon, C. Dinoi and L. Maron, Science, 2017, 358, 1168.

14 (a) A. Causero, H. Elsen, G. Ballmann, A. Escalona and S. Harder, Chem. Commun., 2017, 53, 10386; (b) B. Freitag, J. Pahl, C. Färber and S. Harder, Organometallics, 2018, 37, 469; (c) C. N. de BruinDickason, T. Sutcliffe, C. Alvarez Lamsfus, G. B. Deacon, L. Maron and C. Jones, Chem. Commun., 2018, 54, 786.

15 (a) V. Leich, T. P. Spaniol, L. Maron and J. Okuda, Angew. Chem. Int. Ed., 2016, 55, 4794; (b) D. Schuhknecht, C. Lhotzky, T. P. Spaniol, L. Maron and J. Okuda, Angew. Chem. Int. Ed., 2017, 56, 
12367; (c) M. Wiesinger, B. Maitland, C. Färber, G. Ballmann, C. Fischer, H. Elsen and S. Harder, Angew. Chem. Int. Ed., 2017, 56, 16654.

16 Y. Sarazin, D. Roşca, V. Poirier, T. Roisnel, A. Silvestru, L. Maron and J.-F. Carpentier, Organometallics, 2010, 29, 6569.

17 O. Michel, S. König, K. W. Törnroos, C. Maichle-Mössmer and R. Anwander, Chem. Eur. J., 2011, $17,11857$.

$18 \mathrm{H}_{\mathrm{Si}}$ and $\mathrm{H} 2_{\mathrm{Si}}$ hydrogen atoms linked to silicon atoms were introduced in the structural model through Fourier difference maps analysis.

19 (a) O. Michel, K. W. Törnroos, C. Maichle-Mössmer and R. Anwander, Chem. Eur. J., 2011, 17, 4964; (b) O. Michel, K. W. Törnroos, C. Maichle-Mössmer and R. Anwander, Eur. J. Inorg. Chem., 2012, 44; (c) B. Liu, T. Roisnel, J.-P. Guégan, J.-F. Carpentier and Y. Sarazin, Chem. Eur. J., 2012, 18, 6289; (d) J. P. Davin, J.-C. Buffet, T. P. Spaniol and J. Okuda, Dalton Trans., 2012, 41, 12612; (e) S.-C. Roşca, C. Dinoi, E. Caytan, V. Dorcet, M. Etienne, J.-F. Carpentier and Y. Sarazin, Chem. Eur. J., 2016, 22, 6505; (f) S.-C. Roşca, E. Caytan, V. Dorcet, T. Roisnel, J.-F. Carpentier and Y. Sarazin, Organometallics, 2017, 36, 1269; (g) D. Mukherjee, S. Shirase, K. Beckerle, T. P. Spaniol, K. Mashima and J. Okuda, Dalton Trans., 2017, 46, 8451; (h) E. Le Coz, H. Roueindeji, V. Dorcet, T. Roisnel, J.F. Carpentier and Y. Sarazin, Dalton Trans., 2019, DOI: 10.1039/C9DT00771G.

20 S. Blair, K. Izod, W. Clegg and R. W. Harrington, Inorg. Chem., 2004, 43, 8526.

21 M. Westerhausen and W. Schwarz, J. Organomet. Chem., 1993, 463, 51.

22 M. Gärtner, H. Görls and M. Westerhausen, Z. Anorg. Allg. Chem., 2007, 633, 2025.

23 M. R. Crimmin, A. G. M. Barrett, M. S. Hill, P. B. Hitchcock and P. A. Procopiou, Inorg. Chem., 2007, 46, 10410. 